(C) 2012

Щербакова Н. С., кандидат ветеринарних наук

Полтавська державна аграрна академія

\title{
ВИКОРИСТАННЯ ІМУНОСТИМУЛЯТОРІВ ЗА ВАКЦИНАЦІЇ СВИНЕЙ ВІД БЕШИХИ
}

\section{Рецензент - кандидат ветеринарних наук П. І. Локес}

\begin{abstract}
Деякі вакцини не викликають при застосуванні належної імунної відповіді. Це пов'язано з рівнем резистентності організму, який змінюється незалежно від багатьох факторів, у тому числі й від віку тварин, годівлі, умов утримання, дії на організм хімічних, фізичних, біологічних та інших чинників. Для підвищення імунної відповіді організму та корекції імунного стану організму тварин використовують біогенні стимулятори. Біогенні стимулятори змінюють обмінні й енертетичні прочеси в організмі, активізуючи ферменти. Проведені дослідження щзодо можливості використання біогенних стимуляторів при щеепленні свиней від бешихи інактивованими вакциннами. Вста-

новлено, щзо застосування даних препаратів за вакиинації тварин підвищує еритропоез, кількість B- $і$ T-лімфоцитів, а також активує фатоцитарну активність
\end{abstract}

Ключові слова: свині, імунітет, біогенні препарати, вакцина, імунна відповідь.

Постановка проблеми. Біогенні стимулятори - це біологічно активні речовини, що утворюються в ізольованих тваринних і рослинних тканинах у процесі їхнього пристосування до несприятливих факторів. Біогенні стимулятори утворюються і в тваринному організмі в період його адаптації до несприятливих умов: при опромінюванні, травмах, запальних процесах.

Біогенні стимулятори належать до складного комплексу речовин типу органічних кислот різних груп, а саме: дикарбонових - жирного ряду (щавелева, янтарна); ненасичених жирноароматичних кислот і оксикислот (корична, оксикорична); ароматних кислот із великою молекулярною масою (фенокислоти, гумінові кислоти та інші).

Аналіз основних досліджень і публікацій, у яких започатковано розв'язання проблеми. Біогенні стимулятори рослинного й тваринного походження діють на організм тварин і людини. Підтвердженням цього є зазначений клінічний матеріал багатьох авторів $[1,2,3]$. Біогенні стимулятори змінюють обмінні та енергетичні процеси в організмі, активізуючи ферменти. Активація проходить завдяки сполученню біогенних стимуляторів до білка ферменту. Зміна активності ферментів веде до ендокринної перебудови: підвищується утворення гормонів гіпофізу, зумовлюючих підсилення секреторної функції наднирників, сім'яників, щитовидної і підшлункової залоз. У результаті збільшується інтенсивність включень мічених амінокислот, фосфору i заліза в еритроцити, білки плазми крові та тканини внутрішніх і кровотворних органів, прискорюється відновлення сірковмісних мукополісахаридів [4, 5].

До препаратів, які містять біогенні стимулятори, відносять екстракти із тканин тварин; екстракт та лінімент із соку алое; екстракт плаценти, суспензії з тканин плаценти; ФІБС (водний розчин біогенних стимуляторів із вмістом деяких синтетичних стимуляторів); пелоїдодистилат (біогенні стимулятори, виділені із лиманного багна); торфот (відгон торфу); гумізоль (0,01\%ний розчин фракції гумінових кислот хаапсамульського лікувального багна у фізіологічному розчині); біосед (екстракт із трави очитка великого [Sedum maximum], який містить органічні кислоти ді- і трикарбонового ряду, амінокислоти, полісахариди, макро- та мікробіогенні елементи); гумат натрію або гумінат (натрієва сіль гумінових кислот, яку одержують із торфу шляхом екстракції лугом); скловидне тіло.

Запропоновано ще ряд біогенних стимуляторів. Це - гумоксін, виготовлений із торфу; БС-3 - містить магній; ПДЕ (плацента денатурована емульсована), хоріцен, умбіліцен - препарати виготовлені із плаценти; ербісал або РБС [4].

За результатами досліджень окремі автори відмічають, що тканинні препарати - екстракт алое і витяжка 3 печінки великої рогатої худоби $\epsilon$ ефективним засобом стимуляції імуногенезу й підвищення імунобіологічної реактивності організму під час вакцинації кроликів паратифозною формолвакциною. Дія тканинних препаратів на тварин як у період первинної вакцинації, так і в віддалену ревакцинацію сприяє накопиченню в крові гамаглобулінів, а водночас і специфічних антитіл $[2,4]$. 
У разі одночасного застосування антигену i тканинного біостимулятора проходить активізація не тільки специфічного імунітету, а й неспецифічного гуморального [1].

Під час застосування тканинних препаратів у білкових фракціях сироватки крові відмічається збільшення кількості гамаглобулінів, а на фоні гіперімунізації тварин - і збільшення загальної кількості білку. В 2-3 рази підвищується фагоцитарна активність нейтрофілів, клітин РЄС, утворення специфічних антитіл [4].

Ще одним біологічно активним препаратом $\epsilon$ екстракт трутневого розплоду, який за сумісного введення з різними антигенами стимулює антигенні й імуногенні властивості організму. Він проявляє неспецифічну стимулюючу дію на синтез аглютинінів i забезпечує більш тривалу імунну відповідь [3].

Метою роботи було визначення можливості використання біогенних стимуляторів за щеплення свиней від бешихи інактивованими вакцинами.

Матеріали та методи. Дослідження проводилися на базі кафедри інфекційної патології Полтавської державної аграрної академії, ЦНДЛ УМС, СТОВ ім. Шевченка і державної лабораторії ветеринарної медицини Гадяцького району.

Для проведення досліджень були сформовані групи тварин. Для цього на свинофермі було відокремлено 4 групи свиней по 10 голів у кожній. Групи формувалися за принципом аналогів, враховуючи породу (велика біла), вік (3 місяці), масу тіла (29-31 кг), умови утримання та годівлі.

Першій групі свиней вводили тканинний препарат, другій - концентровану гідроокис алюмінієву формолвакцину проти бешихи «Бешиформ», третій - сумісне введення тканинного препарату і вакцини, а четверта група не отримувала жодного препарату й була контролем.

Тканинний препарат, виготовлений із паренхіматозних органів ВРХ вводили двічі з інтервалом 14 днів внутрішньом'язево за вухом із розрахунку 0,1 мл на 1 кг живої ваги.
Вакцину «Бешиформ» (концентровану ГОА формолвакцину проти бешихи свиней) Дніпропетровської біофабрики вводили двічі з інтервалом 14 днів, доза 3 мл, серія № 2, контроль № 2.

Кров для дослідження відбирали із очного венозного синусу за 1 день до введення препаратів, через 14 днів після першого введення та через 30 днів після другого.

У пробах крові визначали кількість еритроцитів, лейкоцитів, фагоцитарну активність і підраховували кількість Т- і В-лімфоцитів за загальноприйнятими методами.

Результати досліджень. Як видно з огляду літератури, широкої практики в наш час набуло застосування біогенних стимуляторів, як фактора, що активізує обмінні процеси в організмі.

Активізація обмінних процесів веде до підвищення загальної резистентності організму, а це, в свою чергу, дає змогу застосовувати біогенні стимулятори у процесі лікування багатьох хвороб тварин.

Ми вивчали дію тканинних препаратів (ТкП) на імунологічні показники крові свиней за вакцинації проти бешихи.

За один день до введення препаратів кров була досліджена щодо морфологічних і імунних показниках, які майже не відрізнялись у поросят дослідних груп. Кількість еритроцитів знаходилась у межах 5,3 млн/мм ${ }^{3}$, лейкоцитів - 11,2 тис. $/ \mathrm{Mm}^{3}$, у тому числі 23,4 \% становили В-лімфоцити і 30,5 \% - Т-лімфоцити (табл. 1).

На 15-й день дослідження було встановлено, що кількість лейкоцитів у тварин третьої групи достовірно підвищилась і була майже на $32 \%$ вище, ніж у тварин контрольної групи. Кількість лейкоцитів у поросят 1-ї і 2-ї груп також збільшилася.

Слід відмітити, що різниця між кількістю В-лімфоцитів у поросят другої і третьої груп склала $0,3 \%$, а відсоток Т-лімфоцитів у тварин третьої групи вищий на $8 \%$ ніж аналогічний показник у другої групи.

\section{1. Показники імунного статусу тварин за 1 день до застосування препаратів}

\begin{tabular}{|c|c|c|c|c|c|}
\hline $\begin{array}{c}\text { Групи } \\
\text { тварин }\end{array}$ & $\begin{array}{c}\text { Еритроцити, } \\
\text { млн/мм }\end{array}$ & $\begin{array}{c}\text { Лейкоцити, } \\
\text { тис./мм }\end{array}$ & $\begin{array}{c}\text { В-лімфоцити, } \\
\%\end{array}$ & $\begin{array}{c}\text { Т-лімфоцити, } \\
\%\end{array}$ & $\begin{array}{c}\text { Фагоцитарна } \\
\text { активність }\end{array}$ \\
\hline I група (ТкП) & $5,3+0,32$ & $11,2+0,43$ & $23,4+0,36$ & $30,5+0,43$ & $18,2+0,28$ \\
\hline II група (вакц.) & $5,3+0,34$ & $11,2+0,42$ & $23,4+0,34$ & $30,5+0,34$ & $18,2+0,32$ \\
\hline $\begin{array}{c}\text { III група } \\
\text { (ТкП + вакц.) }\end{array}$ & $5,4+0,3$ & $11,2+0,45$ & $23,4+0,35$ & $30,5+0,42$ & $18,2+0,26$ \\
\hline $\begin{array}{c}\text { IV група } \\
\text { (контроль) }\end{array}$ & $5,3+0,31$ & $11,3+0,41$ & $23,2+0,34$ & $30,5+0,44$ & $18,1+0,31$ \\
\hline
\end{tabular}




\section{2. Показники імунного статусу тварин через 15 днів після застосування препаратів}

\begin{tabular}{|c|c|c|c|c|c|}
\hline $\begin{array}{c}\text { Групи } \\
\text { тварин }\end{array}$ & $\begin{array}{c}\text { Еритроцити, } \\
\text { млн/мм }\end{array}$ & $\begin{array}{c}\text { Лейкоцити, } \\
\text { тис./мм }^{3}\end{array}$ & $\begin{array}{c}\text { В-лімфоцити, } \\
\%\end{array}$ & $\begin{array}{c}\text { Т-лімфоцити, } \\
\%\end{array}$ & $\begin{array}{c}\text { Фагоцитарна } \\
\text { активність }\end{array}$ \\
\hline I група (ТкП) & $5,7+0,33$ & $12,4+0,39$ & $27,6+0,02$ & $33,0+0,01$ & $18,6+0,47$ \\
\hline II група (вакц.) & $5,4+0,32$ & $13,1+0,41$ & $29,8+0,38$ & $24,3+0,86$ & $30,7+0,16$ \\
\hline $\begin{array}{c}\text { III група } \\
\text { (ТкП + вакц.) }\end{array}$ & $5,8+0,44$ & $16,5+0,35$ & $30,1+0,45$ & $37,2+0,73$ & $34,9+0,54$ \\
\hline $\begin{array}{c}\text { IV група } \\
\text { (контроль) }\end{array}$ & $5,3+0,31$ & $11,2+0,43$ & $23,4+0,16$ & $31,0+0,65$ & $18,1+0,61$ \\
\hline
\end{tabular}

\section{3. Показники імунного статусу тварин через 30 днів після застосування препаратів}

\begin{tabular}{|c|c|c|c|c|c|}
\hline $\begin{array}{c}\text { Групи } \\
\text { тварин }\end{array}$ & $\begin{array}{c}\text { Еритроцити, } \\
\text { млн/мм }\end{array}$ & $\begin{array}{c}\text { Лейкоцит, } \\
\text { тис./мм }^{3}\end{array}$ & $\begin{array}{c}\text { В-лімфоцити, } \\
\text { \% }\end{array}$ & $\begin{array}{c}\text { Т-лімфоцити, } \\
\%\end{array}$ & $\begin{array}{c}\text { Фагоцитарна } \\
\text { активність }\end{array}$ \\
\hline I група (ТкП) & $6,2 \pm 0,24$ & $12,7 \pm 0,46$ & $37,4 \pm 0,13$ & $40,1 \pm 0,07$ & $19,2 \pm 0,85$ \\
\hline II група (вакц.) & $6,0 \pm 0,35$ & $17,5 \pm 0,35$ & $46,5 \pm 0,51$ & $42,8 \pm 0,23$ & $38,4 \pm 0,43$ \\
\hline $\begin{array}{c}\text { III група } \\
\text { (ТкП + вакц.) }\end{array}$ & $6,3 \pm 0,38$ & $18,9 \pm 0,39$ & $49,0 \pm 0,72$ & $43,4 \pm 0,68$ & $43,5 \pm 0,72$ \\
\hline $\begin{array}{c}\text { IV група } \\
\text { (контроль) }\end{array}$ & $5,3 \pm 0,34$ & $11,2 \pm 0,43$ & $23,4 \pm 0,15$ & $30,7 \pm 0,16$ & $18,4 \pm 0,63$ \\
\hline
\end{tabular}

У поросят контрольної групи кількість В-лімфоцитів на протязі 15-ти днів не змінюється, а кількість Т-лімфоцитів підвищилася на 0,5\% (табл. 2).

Необхідно вказати, що фагоцитарна активність у тварин третьої групи зросла до 34,9 \% iз 18,2 , у той час як цей показник при другому визначенні у тварин першої і другої груп був 18,6 i 30,7 \% відповідно.

Фагоцитарна активність зовсім не підвищилась у поросят контрольної групи, яким не вводили ніяких препаратів.

На 30-й день досліджень кількість лейкоцитів у тварин третьої групи становила 19 тис./мм³ кількість В-лімфоцитів - 49 \%, а Т-лімфоцитів 43 \%. Значно менші показники лейкоцитів В- i Т-лімфоцитів одержані у поросят другої групи,

\section{БІБЛІОГРАФІЯ}

1. Апатенко B. М. Иммуностимуляция при вакцинации телят против инфекционного ринотрахеита крупного рогатого скота / В. М. Апатенко, С. Г. Матковская. - 3б. наук. праць ХДЗВА : Проблеми зооінженерії та ветеринарної медицини. - Вип. 12. - Ч. 2. - 2005. - С. 178-181.

2. Артемов Б. Т. Роль иммуномодуляторов в специфической профилактике инфекционных болезней свиней / Б. Т. Артемов, Т. Н. Ракова, Н. Г. Жмуров. - Тез. докл. 3-й Всесоюз. конф. по эпизоотологии - Новосибирск, 1991. - С. 297-298. що становить $17,5,45,5$ і 42,8 \% відповідно (табл. 3).

Із 15-го по 30-й день фагоцитарна активність у поросят третьої групи зросла на $20 \%$, чого не можна сказати про даний показник у тварин першої і другої груп. У контрольній групі поросят цей показник не підвищився взагалі.

На 30-й день досліджень кількість еритроцитів у поросят контрольної групи була меншою на $15 \%$, аніж у тварин дослідних груп.

Висновок. Із проведеного дослідження можна зробити висновок, що застосовані препарати стимулюють еритропоез, підвищення кількості В- i Т-лімфоцитів, а також фагоцитарної активності в третій групі вказує на стимулюючий вплив тканинного препарату на імунну відповідь.

3. Дрокина E. A. Иммуностимуляция экстрактом трутневого расплода при вакцинации против ньюкаслской болезни / Е. А. Дрокина, В. М. Апатенко. 3б. наук. праць ХДЗВА : Проблеми зооінженерії та ветеринарної медицини. - Вип. 11(35). - Ч. 2. 2003. - С. 184-187.

4. Калашник I. О. Довідник по застосуванню біологічно активних речовин у тваринництві / Калашник I. О. - К. : Урожай. - 1989. - С. 161-178. 5. Колесников А. П. Диагностика и лечение иммунопатологических заболеваний. / А. П. Колесников, А. С. Хабаров. - Барнаул, 2000. - 273 с. 